\title{
CONSIDERATTII PRELIMINARE ASUPRA UNEI INCINTE FUNERARE DIN NECROPOLA ROMANĂ DE INCINERAȚIE DE LA TĂUL SECUILOR-PÂRÂUL PORCULUI, ALBURNUS MAIOR
}

\author{
Cătălina Mihaela Neagu, Ionuț Bocan
}

\section{PRELIMINARY CONSIDERATIONS ABOUT ONE FUNERARY PRECINCT FROM A CREMATION ROMAN NECROPOLIS AT TĂUL SECUILOR-PÂRÂUL PORCULUI, ALBURNUS MAIOR}

Between 2005-2006 was investigated, in the framework of the "Alburnus Maior National Research Program", a rectangular funerary precinct with two functioning phases; its dimensions are $4.50 \times 3.90 \mathrm{~m}$ (the first phase) and $6.00 \times 4.50 \mathrm{~m}$ (the second phase). The funerary precinct is part of the Roman cremation necropolis from Tăul Secuilor-Pârâul Porcului site. Inside the funerary structure three cremation graves were identified and researched, all of them belonging to the general type of graves in this necropolis. Also have been identified four pits which indicate human interventions on the three graves inside the precinct. The funerary inventory is characteristic for the necropolises at Aburnus Maior: pottery, as well as glass and metal objects. The entire complex was dated to the $2^{\text {nd }}$ century A.D.

Cuvinte cheie: incintă funerară, morminte de incinerație, necropolă, inventar funerar, gropi de intervenție Key words: funerary precinct, cremation graves, necropolis, funerary inventory, intervantion pits

\section{Introducere $^{1}$}

Acest studiu preliminar este dedicat analizei unei incinte funerare din necropola romană de incinerație de la Tăul SecuilorPârâul Porcului ${ }^{2}$, perimetru cercetat parțial,

\footnotetext{
${ }^{1}$ Lista abrevierilor utilizate în text: a = adâncimea, Ad. = adâncimea gropii, Ad.a = adâncimea la care a apărut mormântul, cca. $=$ circa, $\mathrm{cm}=$ centimetri, $\mathrm{db}=$ diametrul bazei, dbuton $=$ diamentrul buton, dext $=$ diametrul exterior, $\mathrm{dg}=$ diametrul gură, dint $=$ diametrul interior, dmax $=$ diametrul maxim, $\mathrm{h}=$ înălțimea, hp = înălțimea păstrată, Hp. = înălțimea asizei păstrate, $\mathrm{L}=$ lungimea, $\mathrm{l}=$ lățimea, Lcui = lungimea cui, Lg = lungimea mormântului la nivelul gurii, lg = lățimea mormântului la nivelul gurii, Li = lungimea mormântului în parte inferioară, li = lățimea mormântului în partea inferioară, $\mathrm{Lp}=$ lungimea păstrată, Lpț = lungimea păstrată țintă Lț = lungime țintă, m = metri, pl. = planşă, nr. cat. = număr catalog, Ț $=$ țintă.

${ }^{2}$ Velcea, Savu 1982, 199. Perimetrul din care face parte ansamblul funerar este cunoscut în literatura arheologică de specialitate sub denumirea generică de
}

în cadrul „Programului Național de Cercetare Alburnus Maior”, în campaniile arheologice din anii 2004-2006 ${ }^{3}$.

Deşi monumentul, care face obiectul acestui studiu, este parte componentă dintr-o necropolă cu o problematică deosebit de complexă, caracteristicile sale constructive, amplasamentul particular în economia spațială a obiectivului, dar şi o serie de particularități ale părților sale constitutive, au motivat o abordare separată, cel puțin în stadiul actual al cercetării. În literatura

Tăul Secuilor. În extremitatea vestică perimetrul este marcat de culoarul transversal al cursului de apă cu hidronimul Pârâul Porcului (direcția de curgere NV/SE), motiv pentru care, situl în discuție, este cunoscut sub denumirea de „necropola de la Tăul Secuilor-Pârâul Porcului”.

3 CCA 2006 (2007), 295-300. Mulțumim pe această cale colegei noastre Mihaela Simion pentru sprijinul acordat. 
istorico-arheologică dedicată universului funerar din Dacia romană, publicarea unor astfel de monumente a fost, cu unele excepții ${ }^{4}$, înglobată în prezentarea necropolelor din care făceau parte. De aceea, abordarea în detaliu a unei astfel de construcții, cu o specială atenție asupra detaliilor arheologice, ar constitui, credem noi, un demers util pentru o viitoare abordare de tip monografic, dedicată descoperirilor de acest tip din Dacia romană.

În campaniile de cercetare arheologică din anii 2005-2006 a fost identificată şi cercetată o incintă funerară ${ }^{5}$. Monumentul este amplasat în partea de nord-vest a necropolei de la Tăul Secuilor-Pârâul Porcului, în unitățile de săpătură cu siglele S 010901 194, carourile 15 (caroul 1/a), 16 (carourile1-6/a-e), 17 (caroul 6/f), 18 (carourile 1-6/b-f), 19 (carourile 4-6/d-f) ${ }^{6}$.

Din punctul de vedere al cronologiei relative, au fost sesizate două faze de construcție, trei înmormântări şi patru gropi de intervenție. Construcția este orientată pe axa NNE-SSV. În prima fază de funcționare incinta are dimensiunile de 4,50 × 3,90 m, iar în cea de-a doua fază de 6,00 × 4,50 m (pl. 1).

\section{Caracteristici stratigrafice (pl. 2)}

În cadrul stratigrafiei generale a necropolei ${ }^{7}$, cea internă a monumentului se individualizează prin caracteristicile generate

\footnotetext{
${ }^{4}$ Alburnus Maior (Simion et alli 2004), Ulpia Traiana Sarmizegetusa, Mausoleul Aureliilor (Daicoviciu, Floca 1937, 1-23), incinta funerară de pe Valea Draşcovului (Daicoviciu et alli 1975, 225-232).

5 Situl arheologic, în cadrul căruia a fost descoperit ansamblul funerar, este amplasat în partea de NV a actualei localităţi Roşia Montană. Din punct de vedere geografic, perimetrul pe care au fost identificate şi cercetate complexele, este poziționat pe un platou, aflat la altitudinea relativă de $760 \mathrm{~m}$.

6 Coordonate Stereo 70. Forma incintei este rectangulară în ambele faze de funcționare; construcția este orientată pe axa NNE-SSV. Din punct de vedere metodologic caroiajul a fost unul unitar cu cel folosit pentru cercetarea necropolei, din metru în metru, pe axa $\mathrm{N}-\mathrm{S}$ s-au folosit cifre, iar pe axa V-E litere. Acest caroiaj a fost utilizat în interiorul careurilor de $6 \times 6 \mathrm{~m}$. ${ }^{7}$ CCA 2004 (2005), nr. 187, 293-294.
}

de construcția unei astfel de amenajări. Stratigrafia internă ${ }^{8}$ (pl. 2) a incintei funerare este prezentată în continuare (într-o ordine inversă a depunerilor sedimentare), porninduse de la stratul superior către bază, după cum urmează:

1. Sol vegetal de culoare cenuşie (orizontul organic al solului actual), $\mathrm{cu} \mathrm{O}$ grosime de cca. 0,15 $\mathrm{m}^{9}$; nisipos, omogenitate slabă; are în compoziție pietriş, resturi vegetale şi organice.

2. Nivel de argilă siltică, de culoare brun-negriciosă, cu o grosime de cca. 0,27 m; în compoziție s-au putut observa fragmente de rocă demineralizată, fragmente ceramice de factură romană, pigmenți de cărbune şi de sol ars. Este întrerupt pe anumite porțiuni datorită intervențiilor ulterioare (G1, G2, G3, G4), care sunt practicate de la acest nivel. Este nivelul de la care au fost amenajate gropile M 270 şi M 271.

3. Nivel de argilă siltică, de culoare galbenă ${ }^{10}$, lutos, cu o grosime de cca. 0,46 m, compact, are în compoziție fragmente de şisturi argiloase, oxizi de fier, pigmenți de cărbune, sol ars, fragmente ceramice de factură romană (poziționate la partea superioară a nivelului). De la acest nivel a fost amenajată prima groapă sepulcrală, M 268. Având în vedere configuraţia terenului, pentru a se realiza un plan orizontal, care să permită construcția zidurilor din prima fază, a fost aleasă soluția unei nivelări.

4. Sediment de culoare brun-maronie, care prezintă în partea superioară un nivel de pietre $^{11}$, cu o grosime maximă de $0,32 \mathrm{~m}$;

\footnotetext{
${ }^{8}$ Stratigrafia din interiorul ansamblului funerar este una tipică pentru mormintele tumulare, însă aceste amenajări exterioare, care au fost realizate pentru prima şi a doua înmormântare, au fost în bună parte distruse de construcția ultimei gropi sepulcrale (M 270), care, practic, utilizează perimetrul rezervat primei înmormântări, şi respectiv de realizarea zidului de nord din faza a doua de funcționare $\mathrm{Z} 1$.

${ }^{9}$ Au fost luate în considerare dimensiunile maxime.

${ }^{10}$ Sedimentul are variații de ordin cromatic de la galben deschis la galben roşcat.

${ }^{11}$ De dimensiuni medii.
} 
reprezintă mantaua tumulului corespunzătoare primei înmormântări (M 268).

5. Nivel de argilă siltică, de culoare galbenă, lutos, compact, cu o grosime maximă $0,54 \mathrm{~m}^{12}$, care are în compoziție gresii, conglomerate şi concentrații de oxizi de fier.

6. Nivel de argilă siltică, de culoare galbenă-maronie, cu o grosime maximă de 0,32 m, reprezentând mantaua corespunzătoare complexului M 271(?) ${ }^{13}$.

7. Nivel de sedimente de culoare cenuşie reprezentând umplutura şanțului de fundație a zidurilor Z 1 şi Z 5.

\section{Caracteristici constructive (pl. 1)}

În cursul cercetării au fost identificate traseele a şapte ziduri, corespunzătoare celor două faze de funcționare a incintei funerare. Acestea au fost denumite convențional Z1, Z2a, Z2b, Z3, Z4a, Z4b, Z5 ${ }^{14}$.

Z1: construit din blocuri de piatră fasonate, orientat: ENE-VSV; dimensiuni: L $=4,50 \mathrm{~m} ; \mathrm{l}=0,40-0,60 \mathrm{~m} ; \mathrm{Hp}=0,10-0,15$ $\mathrm{m}^{15}$; zidul se păstrează pe înălțimea a trei asize. Este vizibil şanţul de fundaţie, cu o lățime de aproximativ $0,80 \mathrm{~m}$ şi o adâncime de aproximativ 0,50 m. În umplutura acestuia s-au observat pietre de dimensiuni mici, precum şi fragmente ceramice romane, rulate probabil, din partea de nord a necropolei. Blocurile de piatră utilizate pentru elevaţie prezintă urme de prelucrare. Ultima asiză păstrată este uşor deplasată spre interior, cu aproximativ $0,20 \mathrm{~m}$, această situație fiind firească datorită presiunii exercitate pe direcția de înclinare a pantei, de la NE spre SV.

\footnotetext{
${ }^{12}$ Grosimea maximă până la cota la care s-a cercetat.

${ }^{13}$ Datorită şanțului de fundație a Z1, mantaua tumulului a fost puternic afectată.

14 Zidurile au fost numerotate în ordinea apariției şi descoperirii lor.

15 Dimensiunile sunt variabile, dat fiind faptul că blocurile de piatră sunt dispuse progresiv, pietre mari la bază pentru ca, în partea superioară acestea să fie de dimensiuni mai mici, excepție făcând cele de tipul chaperon, reprezentând ultima asiză.
}

Z2a: construit din blocuri de piatră nefasonate, orientat: NNE-SSV; dimensiuni: $\mathrm{L}=3,90 \mathrm{~m} ; \mathrm{l}=0,80-1,00 \mathrm{~m} ; \mathrm{Hp}=0,60 \mathrm{~m}$; zidul se păstrează pe înălțimea a două asize ${ }^{16}$. Şanțul de fundație are dimensiuni de aproximativ 1,00 m lăţime, şi o adâncime de aproximativ 0,60-0,70 m, în fundația zidului fiind utilizate blocuri mari de piatră, $\mathrm{cu}$ dimensiuni de aproximativ 1,00 × 0,80 × 0,70 m. Blocurile de piatră din fundație nu prezintă urme de prelucrare, iar blocurile din cele două asize din elevație păstrate prezintă uşoare urme de prelucrare (situație identică şi pentru Z4a).

Z2b: construit din blocuri de piatră fasonate, orientat NNE-SSV; dimensiuni: L $=6,00 \mathrm{~m} ; \mathrm{l}=0,40-0,60 \mathrm{~m}$; zid din faza a doua de funcționare a incintei; a fost construit iniţial pe înălţimea a cinci asize şi reutilizează o parte din elevația zidului de est din faza I de construcție a incintei (Z2a); ultimele patru asize sunt uşor deplasate sau chiar căzute în imediata apropiere. Ultima asiză este din piatră fasonată într-o manieră particulară, respectiv sub forma unui capac în două ape (chaperon), cu dimensiunile de 1,20 × 0,80 $\times$ $0,20 \mathrm{~m}$.

Z3: construit din blocuri de piatră nefasonate, orientat: ENE-VSV; dimensiuni: $\mathrm{L}=3,90 \mathrm{~m} ; \mathrm{l}=0,80-1,00 \mathrm{~m}$; se păstrează pe înălțimea a două asize ${ }^{17}$. În partea centrală, zidul se întrerupe, pe această porțiune fiind identificat un nivel constituit din pietre de dimensiuni medii şi mici, tasate în solul galben (posibilă urmă de substrucție a unei platforme pentru un monument funerar, $\mathrm{Cpl}$ $1)^{18}$. Şanţul de fundație are dimensiuni de aproximativ $1,00 \mathrm{~m}$ şi $\mathrm{o}$ adâncime de aproximativ $0,60-0,70 \mathrm{~m}$. Fundația zidului este constituită din blocuri mari de piatră cu dimensiuni variabile, cuprinse între $2,20 \times$

\footnotetext{
16 La nivelul zidului au fost observate pietre de dimensiuni medii pentru întărirea acestuia.

${ }^{17}$ Blocuri de piatră ce par să fi făcut parte din elevația acestui zid, au fost găsite la baza pantei, în poziție secundară, în unitățile de săpătură cu siglele S 010901 168, S 010901176 şi S 010901177.

${ }^{18}$ Vezi infra nota 24.
} 
$1,00 \times 0,60 \mathrm{~m}$ şi $1,00 \times 0,80 \times 0,70 \mathrm{~m}$. Din elevația acestui zid nu s-au găsit în poziție inițială decât blocuri de piatră din prima fază de construcție.

Z4a: construit din blocuri de piatră nefasonate, orientat: NNE-SSV; dimensiuni: $\mathrm{L}=3,90 \mathrm{~m} ; \mathrm{l}=0,80-1,00 \mathrm{~m}$; zidul se păstrează pe înălțimea a trei asize. Şanțul de fundație are dimensiuni de aproximativ 1,00 m lățime şi o adâncime de aproximativ 0,60$0,70 \mathrm{~m}$; fundația zidului este constituită din blocuri mari de piatră cu dimensiuni cuprinse între $2,20 \times 1,00 \times 0,60 \mathrm{~m}$ şi $1,00 \times 0,80 \times$ $0,70 \mathrm{~m}$. Pe acest zid a fost descoperit un fragment de cornişă. Acest fragment de cornişă in situ constituie argumentul că prima fază de funcționare a fost ridicată pe înălțimea a trei asize în partea de vest. Datorită configuraţiei terenului putem presupune că în partea de sud zidul era mai înalt pentru a conferi stabilitate monumentului.

Z4b: construit din blocuri de piatră fasonate, orientat: NNE-SSV; dimensiuni: L $=6,00 \mathrm{~m} ; \mathrm{l}=0,40-0,60 \mathrm{~m}$; a fost construit pe cinci asize, ultimele patru fiind uşor deplasate sau chiar în poziție secundară, în imediata apropiere. Zidul din faza a doua a incintei a fost construit inițial ${ }^{19}$ pe înălțimea a cinci asize şi reutilizează o parte din elevația zidului de est din faza I de construcție a incintei (Z4a). Ultima asiză este din piatră fasonată într-o manieră particulară, respectiv sub forma unui capac în două ape (chaperon), cu dimensiunile de 1,30 × 0,80 ×0,20 m.

Z5: construit din blocuri de piatră nefasonate, orientat: ENE-VSV; dimensiuni: $\mathrm{L}=3,90 \mathrm{~m} ; \mathrm{l}=0,80-1,00 \mathrm{~m}$; zidul se păstrează pe înălțimea unei singure asize. Şanțul de fundație are dimensiuni de aproximativ 0,50 m lățime, şi o adâncime de aproximativ 0,20-0,30 m; În partea de vest a zidului se mai păstrează un fragment dintr-un bloc de piatră, ceea ce poate sugera faptul că

\footnotetext{
${ }^{19}$ Se păstrează în poziție inițială doar două blocuri de piatră.
}

zidul a fost construit pe înălțimea minimă a două asize, ce probabil au fost reutilizate în a doua fază de construcție.

Pe baza acestor caracteristici am putut distinge două faze de funcționare a incintei funerare. De fapt este vorba de o construcție inițială, descrisă de Z2a (zidul de est); Z3 (zidul de sud), Z4 (zidul de vest) şi $\mathbf{Z 5}$ (zidul de nord). În această fază construcția are o lungime de 4,50 m şi o lățime de 3,90 m şi adăpostea cel puțin unul dintre complexele funerare $^{20}$.

Cea de-a doua fază constructivă, descrisă de zidul de nord, Z22b, zidul de est, $\mathbf{Z 4 b}$, zidul de vest, Z3, zidul de sud (nu s-au păstrat decât pietre din prima fază), cu o lungime de $6,00 \mathrm{~m}$ şi o lățime de $4,50 \mathrm{~m}$, este, mai degrabă, o extindere a incintei cu $1,78 \mathrm{~m}$ spre nord, probabil din necesități legate de insuficiența spațiului funerar consacrat. Astfel, $\mathrm{Z5}^{21}$ este parțial dezafectat, în timp ce funcționalitatea zidurilor de est şi de vest, din prima fază de construcție (Z2a şi Z4a) este păstrată, fiind adăugate la elevație alte cinci noi asize ${ }^{22}$.

La nivelul zidului de sud (Z3), unde acesta este întrerupt, a fost identificată o substrucție a unei platforme, Cpl. $1^{23}$ pentru un monument funerar; de această amenajare pot fi legate câteva piese ce fac parte dintr-o stelă funerară; trei fragmente dintr-un medalion funerar, găsite în interiorul amenajării, precum şi un fragment de cornişă şi un bloc de piatră decorat pe o latură, găsite în poziție secundară la baza pantei ${ }^{24}$. Această amenajare are dimensiunile prezervate de: $\mathrm{L}$ $=1,10 \mathrm{~m} ; \mathrm{l}=0,77 \mathrm{~m} ; \mathrm{Hp}=0,30 \mathrm{~m}$.

\footnotetext{
${ }^{20}$ M 268, vezi infra Descrierea mormintelor, p. 97.

${ }^{21}$ Zidul din prima fază a incintei, păstrat pe o asiză.

22 În poziție inițială au fost surprinse trei asize pentru Z2b şi una pentru Z4b, anastiloza fiind posibilă pe baza poziționării restului de blocuri suprinse in situ.

${ }^{23}$ Abegg-Wigg 2000, 113, 12.2. Platforme de acest tip au fost frecvent semnalate de literatura istorico arheologică, Simion et alii 2004, nota 23; vezi infra nota 19 , p. 96.

${ }^{24}$ Piese ce provin, probabil, din monumentul funerar al incintei.
} 
La nivelul zidului de vest, din prima fază de construcție, Z4a, a fost identificat un bloc de cornişă, ce poate constitui coronamentul zidului.

\section{Descrierea mormintelor:}

În interiorul ansamblului funerar au fost identificate şi cercetate trei morminte de incinerație (M 268, M 270, M 271) ${ }^{25}$. Toate cele trei gropi sepulcrale au suferit perturbări antropice (G 1, G 2, G 3, G 4).

M 268. (pl. 3) ${ }^{26}$ ardere pe loc.

Localizare: S 010901 194, careul 17 şi 18, carourile 3-5/b-e, 3-5/c-f (partea centrală a incintei, faza I).

Dimensiuni: $\mathrm{Lg}=1,88 \mathrm{~m}$; $\lg =0,98 \mathrm{~m}$; $\mathrm{Li}=1,10 \mathrm{~m} ; \mathrm{li}=0,52 \mathrm{~m} ; \mathrm{Ad}=0,68 \mathrm{~m}$; Ad.a $=0,46 \mathrm{~m}(\mathrm{~S}), 0,60 \mathrm{~m}(\mathrm{~N})$.

\section{Orientare: NV-SE.}

Mormânt tumular, afectat parțial datorită perturbării antropice ulterioare şi a amenajării gropii sepulcrale a complexului cu sigla M 270. Tumulul este încadrat de construcția rectangulară reprezentând prima fază a incintei. Groapă de formă rectangulară, prevăzută cu treaptă pe laturile lungi; pereții înclinați, prezintă puternice urme de ardere (arsura continuă are o grosime de 0,05-0,08 $\mathrm{m})$; forma gropii în secțiunea transversală este trapezoidală, partea inferioară a gropii este plată. Groapa sepulcrală a fost sigilată cu dale de piatră ${ }^{27}$. Lespezile păstrate ${ }^{28}$ au dimensiuni de 0,60 ×0,40 ×0,10 m; în partea de est, sunt parțial deranjate de o perturbare antropică (G 1).

\footnotetext{
25 Numerotarea mormintelor este continuă cu siglele utilizate în restul necropolei.

${ }^{26}$ Cotele din text şi cele figurate pe desen sunt de la ax.

${ }^{27}$ În necropola de la Tăul Secuilor-Pârâul Porcului au mai fost cercetate două morminte care dispun de o astfel de sigilare cu dale de piatră M $154(1,76 \times 0,76 \times$ $0,58 \mathrm{~m})$, M $156(2,10 \times 0,65 \times 0,45 \mathrm{~m})$, complexe cercetate în campania 2004 de o echipă formată din Mihaela Simion, Gabriel Bălan, Ionuț Bocan, Emil Dumitraşcu, Cătălina Mihaela Neagu, Mihai Vasile, Decebal Vleja (MNIR).

${ }^{28}$ Se păstrează patru fragmente.
}

Sedimentul de umplutură al gropii sepulcrale este de culoare galben-maronie, conține pigmenți de cărbune şi pământ ars de culoare cărămizie.

Stratul de reziduuri ale cremaţiei (cărbune în amestec cu fragmente de oase calcinate şi cenuşă) este distribuit uniform pe toată suprafața gropii şi are o grosime de 0,15 m. Perturbarea antropică (G 1$)^{29}$ interferează nivelul de reziduuri ale cremației. $\mathrm{Nu}$ se constată nici un tratament intermediar, resturile cremației fiind depuse fără separare de resturile rugului.

Inventar: ceramică: două urcioare, două turibula, două oale, o cupă, şapte opaițe şi două vase nedeterminabile ca formă; sticlă: un unguentarium; obiecte din metal: o cheie, o scoabă, 10 piroane, şase cuie şi o țintă.

1. Urcior miniatural de tip U $\mathbf{2 9}^{30}$ (întregit); dg = 3,4 cm; dmax $=11 \mathrm{~cm}$; db = 5,5 $\mathrm{cm} ; \mathrm{h}=14,4 \mathrm{~cm}$. Pastă RM $8^{31}$; ardere primară uniformă; uşor afectată de aciditatea solului. Corp deformat (pl. 4/1) ${ }^{32}$.

2. Urcior nedeterminabil ca tip (fragmentar, se păstrează corpul şi baza); dmax = 11,2 cm; db = 6,2 cm; hp = 11,2 cm. Pastă RM 8; ardere primară uniformă; uşor afectată de aciditatea solului. Corp globular, deformat. Bază inelară cu umbo în centru (pl. 4/2).

3. Turibulum nedeterminabil ca tip (fragmentar, se păstrează trei fragmente de buză cu corp şi un fragment din picior); dg $=24 \mathrm{~cm}$. Pastă RM 10; ardere primară uniformă; slabe urme de ardere secundară; uşor afectată de aciditatea solului. Buză înclinată spre exterior, uşor arcuită, decorată cu alveole mici, realizate prin presarea cu degetele a celor două margini când pasta este crudă. Picior gol pe interior (pl. 4/3).

\footnotetext{
${ }^{29}$ Infra, intervenții asupra monumentului, p. 105.

30 Determinarea formelor a fost făcută prin încadrarea în tipologia generală a ceramicii descoperită în necropola de la Tăul Cornei, realizată de un colectiv format din Viorica Rusu Rusu-Bolindeț, Adela Bâltâc, Ionuț Bocan şi Mariana Egri; Alburnus Maior III (sub tipar).

${ }^{31}$ Pastele au fost încadrate în codurile de materie primă, stabilite pentru lotul ceramic din necropola de la Tăul Cornei. Alburnus Maior III, 2008 (sub tipar).

${ }^{32}$ Reprezentarea grafică a obiectelor a fost realizată de Andra Samson.
} 
4. Turibulum nedeterminabil ca tip (fragmentar, se păstrează patru fragmente de buză cu corp şi un fragment din picior); dg = $18 \mathrm{~cm}$; db $=7$ cm. Pastă RM 10; ardere primară uniformă; ardere secundară pe interior şi exterior; urme de substanță organică la interior. Buză înclinată spre exterior, arcuită, decorată cu alveole mici, realizate prin presarea cu degetele a marginii superioare când pasta este crudă. Corpul are forma unei cupe, care păstrează o profilatură. Picior gol pe interior. Bază uşor profilată (pl. 4/4).

5. Oală miniaturală nedeterminabilă ca tip (fragmentară, se păstrează un fragment din buză, toarta şi fragmente din corp); dg = 8,5 cm. Pastă RM 1; ardere primară uniformă; uşor afectată de aciditatea solului. Buză înclinată spre exterior, rotunjită, uşor îngroşată. Este prevăzută cu o toartă lată, necanelată, ataşată sub buză (pl. 4/5).

6. Oală nedeterminabilă ca tip (fragmentară, se păstrează un fragment de bază cu corp şi şase fragmente din corp); $d b=7,7 \mathrm{~cm}$. Pastă RM 10; ardere primară incompletă; puternic arsă secundar atât la interior cât şi pe exterior; uşor afectată de aciditatea solului (pl. 5/6).

7. Cupă nedeterminabilă ca tip, imitaţie de vas cu pereți fini (fragmentară, se păstrează un fragment de buză cu corp, un fragment din corp şi altul din bază); dg = $6 \mathrm{~cm}$; hp = 2,2 cm. Pastă RM 5; ardere primară uniformă; uşor afectată de aciditatea solului. Buză înclinată spre exterior, uşor îngroşată şi rotunjită. Corp globular (?). Bază inelară (pl. 5/7).

8. Opaiț Loeschcke X (întregit); $L=9,7$ cm; l = 6,9 cm; h = 3,5 cm. Pastă RM 3; ardere primară uniformă; afectată de aciditatea solului. Disc neted, rotund, cu un orificiu de alimentare în centru, delimitat de bordură printr-un cordon, care se îndreaptă spre cioc şi formează un canal, prevăzut cu un mic orificiu de aerisire. Bordura lată, înclinată este prevăzută cu trei butoni dispuşi aproximativ simetric. Cioc alungit, rotunjit, cu un arzător. Rezervor tronconic. Baza concavă (?) (pl. $5 / 8)$.

9. Opait Loeschcke X (întregit); L = 9,3 cm; l = 6,2 cm; h = 3,2 cm. Pastă RM 11; ardere primară uniformă; ardere secundară pe capac şi cioc; uşor afectată de aciditatea solului. Disc neted, rotund, cu un orificiu de alimentare în centru, delimitat de bordură printr-un cordon proeminent, care se îndreaptă spre cioc şi formează un canal prevăzut cu un mic orificiu de aerisire. Bordura lată, înclinată este prevăzută cu trei butoni dispuşi aproximativ simetric. Cioc alungit, cu un arzător în formă de vârf de săgeată arondat. Rezervor tronconic (pl. 5/9).

10. Opaiț Loeschcke $X$ (fragmentar, lipsesc fragmente din capac şi cioc); $\mathrm{Lp}=7,8 \mathrm{~cm}$; $\mathrm{l}=6,3 \mathrm{~cm} ; \mathrm{h}=3,5 \mathrm{~cm}$. Pastă RM 11; ardere primară uniformă; puternic ars secundar pe bordură şi rezervor; afectată de aciditatea solului. Disc rotund, delimitat de bordură printr-un cordon, care se îndreaptă spre cioc şi formează un canal, prevăzut cu un mic orificiu de aerisire. Bordura lată, înclinată, este prevăzută cu doi butoni dispuşi aproximativ simetric. Cioc cu un arzător. Rezervor tronconic. Baza, delimitată prin trei cercuri concentrice incizate are înscrisă în centru ştampila CAS[SI] (pl. 5/10)

11. Opaiț nedeterminabil ca tip (fragmentar, se păstrează un fragment din rezervor şi două din bază cu dimensiuni de $4 \times 2,9$ cm); Pastă RM 5; ardere primară uniformă; uşor afectată de aciditatea solului. Bază uşor concavă, delimitată prin două cercuri concentrice, incizate (pl. 5/11).

12. Opait nedeterminabil ca tip (fragmentar, se păstrează 26 de fragmente cu dimensiuni cuprinse între 0,8-4 cm); Pastă RM 5; ardere primară uniformă; puternic afectată de aciditatea solului. Bordură lată. Rezervor tronconic (pl. 5/12).

13. Opaiț nedeterminabil ca tip (fragmentar, se păstrează trei fragmente din bază cu dimensiuni cuprinse între 1,8-2,1 cm); Pastă RM 5; ardere primară incompletă. Baza delimitată de două cercuri concentrice incizate are înscrisă în centru ştampila OP[TATI] (pl. 5/13).

14. Opaiț nedeterminabil ca tip (fragmentar, se păstrează un fragment din cioc cu dimensiuni de $2 \times 1,7 \mathrm{~cm}$ ); Pastă RM 8; ardere primară uniformă; puternic afectată de aciditatea solului. Cioc rotunjit (pl. 5/14).

15. Vas nedeterminabil ca formă (fragmentar, se păstrează un fragment din corp cu dimensiuni de $5 \times 3,5 \mathrm{~cm}$ ); Pastă RM 4; ardere primară uniformă; puternic ars secundar; uşor afectată de aciditatea solului. Corp decorat cu două caneluri (pl. 5/15). 
16. Vas nedeterminabil ca formă (fragmentar, se păstrează şase fragmente din corp cu dimensiuni cuprinse între 2-4 cm); Pastă RM 1; ardere primară uniformă; puternic afectată de aciditatea solului.

17. Vas nedeterminabil ca formă (fragmentar, se păstrează trei fragmente din toartă); Pastă RM 3; ardere primară uniformă; afectată de aciditatea solului. Toartă lată, necanelată (pl. 6/17).

18. Unguentarium (fragmentar, se păstrează două fragmente din buză, unul din corp şi alte fragmente puternic vitrifiate); dg $=4 \mathrm{~cm}$. Sticlă subțire, suflată liber, verzuie, transparentă, cu mici bule de aer şi striații în compoziție, neirizată; puternic vitrifiată. Buză rotunjită (pl. 6/18).

19. Cheie (întreagă); L = 7,6 cm. Fier oxidat, corodat. Nerestaurată. Cap inelar. Corp aplatizat, cu secțiune patrulateră. Partea activă este plată şi nu prezintă dantură (pl. 6/19).

20. Scoabă (fragmentară); Lp = 6,3 cm. Fier oxidat, corodat. Nerestaurată. Bară parțial păstrată, cu secțiune dreptunghiulară: $0,9 \times 0,2$ cm. Un cui rupt, celălalt păstrat în totalitate, cu vârf lăţit: Lcui = 1,5 cm (pl. 6/20).

21. Piron (întreg); L $=8 \mathrm{~cm}$. Fier oxidat, corodat. Nerestaurat. Cap rotund, bombat. Corp îndoit spre partea inferioară, cu secțiune pătrată: 0,4 cm. Vârf uşor tocit (pl. 6/21).

22. Piron (fragmentar); $\mathrm{Lp}=6,4 \mathrm{~cm}$. Fier oxidat, corodat. Nerestaurat. Cap rotund, bombat. Corp puternic îndoit, cu secțiune pătrată: 0,5cm. Vârf rupt (pl. 6/22).

23. Piron (fragmentar); Lp =6,2 cm. Fier oxidat, corodat. Nerestaurat. Cap rotund, bombat. Corp drept, puternic afectat de coroziune, cu secțiune patrulateră: $0,6 \times 0,5 \mathrm{~cm}$. Vârf rupt (pl. $6 / 23)$.

24. Piron (fragmentar); Lp $=5,6 \mathrm{~cm}$. Fier oxidat, corodat. Nerestaurat. Cap rotund, afectat de coroziune. Corp îndoit, cu secțiune patrulateră: $0,6 \times 0,5$ cm. Vârf rupt (pl. 6/24).

25. Piron (fragmentar); Lp $=5,5 \mathrm{~cm}$. Fier oxidat, corodat. Nerestaurat. Cap rotund, puternic afectat de coroziune. Corp afectat de coroziune, cu secțiune pătrată: 0,5 cm. Vârf rupt (pl. 6/25).

26. Piron (fragmentar); $\mathrm{Lp}=4,3 \mathrm{~cm}$. Fier oxidat, corodat. Nerestaurat. Cap rotund, puternic afectat de coroziune. Corp parțial păstrat, afectat de coroziune, cu secțiune pătrată: 0,5 cm. Vârf rupt (pl. 6/26).

27. Piron (fragmentar); $\mathrm{Lp}=3,6 \mathrm{~cm}$. Fier oxidat, corodat. Nerestaurat. Cap rotund, afectat de coroziune. Corp parțial păstrat, puternic afectat de coroziune, cu secțiune rectangulară. Vârf rupt (pl. 6/27).

28. Piron (fragmentar); Lp $=3,6 \mathrm{~cm}$. Fier oxidat, corodat. Nerestaurat. Cap rotund, puternic afectat de coroziune. Corp cu secțiune pătrată: 0,5 cm. Vârf rupt (pl. 6/28).

29. Piron (fragmentar); Lp $=3,5 \mathrm{~cm}$. Fier oxidat, corodat. Nerestaurat. Cap rotund, puternic afectat de coroziune. Corp parțial păstrat, cu secțiune pătrată: 0,6 cm. Vârf rupt (pl. 6/29).

30. Piron (fragmentar); $\mathrm{Lp}=3,5 \mathrm{~cm}$. Fier oxidat, corodat. Nerestaurat. Cap rotund, puternic afectat de coroziune. Corp afectat de coroziune, cu secțiune pătrată: 0,4 cm. Vârf rupt (pl. 6/30).

31. Cui (întreg); $L=5,3 \mathrm{~cm}$. Fier oxidat, corodat. Nerestaurat. Cap rotund, bombat, afectat de coroziune. Corp puternic afectat de coroziune, cu secțiune pătrată: 0,3 cm. Vârf îndoit, uşor tocit (pl. 6/31).

32. Cui (fragmentar); $L p=5 \mathrm{~cm}$. Fier oxidat, corodat. Nerestaurat. Cap rotund, puternic afectat de coroziune. Corp afectat de coroziune, cu secțiune pătrată: 0,5 cm. Vârf rupt (pl. 6/32).

33. Cui (fragmentar); $L p=3 \mathrm{~cm}$. Fier oxidat, corodat. Nerestaurat. Cap rupt. Corp puternic afectat de coroziune, cu secțiune patrulateră: 0,4 × 0,3 cm. Vârf rupt (pl. 6/33).

34. Cui (fragmentar); $L p=3 \mathrm{~cm}$. Fier oxidat, corodat. Nerestaurat. Cap rupt. Corp puternic afectat de coroziune, cu secțiune pătrată: 0,3 cm. Vârf tocit (pl. 6/34).

35. Cui (fragmentar); $\mathrm{Lp}=2,7 \mathrm{~cm}$. Fier oxidat, corodat. Nerestaurat. Cap rotund, afectat de coroziune. Corp parțial păstrat, puternic afectat de coroziune. Vârf rupt (pl. 6/35).

36. Cui (fragmentar); Lp $=2,5 \mathrm{~cm}$. Fier oxidat, corodat. Nerestaurat. Cap rupt. Corp afectat de coroziune, cu secțiune pătrată: 0,4 cm. Vârf rupt (pl. 6/36).

37. Țintă (fragmentară); Lp = 1,8 cm. Fier oxidat, corodat. Nerestaurată. Cap rupt. Corp parțial păstrat, puternic afectat de coroziune. Vârf tocit (pl. 6/37). 
M 270 (pl 7) ${ }^{33}$ ardere pe loc.

Localizare: situat în partea de nord a primei faze de construcție a incintei, în S 01 0901194 careul 17 şi 18, carourile 3-5/b-e, 3-5/c-f.

Dimensiuni: $\mathrm{L}=1,50 \mathrm{~m}$; $\mathrm{l}=0,80 \mathrm{~m}$; $\mathrm{Li}=1,20 \mathrm{~m} ; \mathrm{li}=0,60 \mathrm{~m}$; Ad $=0,50 \mathrm{~m}$; Ad. $\mathrm{a}=$ $0,78 \mathrm{~m}$.

\section{Orientare: NV-SE.}

Groapa este de formă ovală în partea de vest şi trapezoidală în secțiune transversală. Groapa este arsă (arsură discontinuă cu o grosime de $0,03-0,06 \mathrm{~m}$ ). Groapa a fost sigilată cu dale de piatră din care s-au păstrat, în jumătatea de est, două dale de piatră $(0,86$ $\times 0,40 \times 0,10 \mathrm{~m}$ ).

Sedimentul de umplutură al gropii sepulcrale este de culoare galben-maroniu, conține pigmenți de cărbune şi pământ ars de culoare roşie. Stratul de reziduuri ale cremației a fost observat pe toată suprafața gropii $0,08 \mathrm{~m}$. Laturile de sud şi vest sunt parțial afectate de o perturbare antropică (G $3)^{34}$, care interferează nivelul de reziduuri ale cremației. Nu se constată nici un tratament intermediar, resturile cremaţiei nefiind separate de resturile rugului. Atât în sedimentul de umplutură al gropii, cât şi pe nivelul de reziduuri ale cremației au fost găsite fragmente de răşină, cu dimensiuni cuprinse între 0,02 şi $0,05 \mathrm{~m}$.

Inventar: sticlă: o margea; obiecte din metal: un topor, patru piroane şi un cui.

1. Mărgea (întreagă); dext $=1,4 \mathrm{~cm}$; dint = $0,7 \mathrm{~cm} ; \mathrm{h}=1 \mathrm{~cm}$. Sticlă vitrifiată, de culoare verde. Mărgea în formă de pepene, tipul I/3 Gudea-Bajusz (pl. 8/1).

2. Topor (întreg). $\mathrm{L}=13 \mathrm{~cm}$, ltăiş $=5,4 \mathrm{~cm}$, Imuchie $=3 \mathrm{~cm}$; Fier oxidat, corodat. Nerestaurat. Muchia plată. Secțiune pentru înmănuşare circulară. Lama, cu secțiune triunghiulară, lățită spre tăiş. Tăiş convex (pl. 8/2).

3. Piron (fragmentar); $\mathrm{Lp}=8,6 \mathrm{~cm}$. Fier oxidat, corodat. Nerestaurat. Cap rotund, puternic

\footnotetext{
${ }^{33}$ Cotele din text şi cele figurate pe desen sunt de la ax.

${ }^{34}$ Vezi infra, intervenții asupra monumentului, p. 105.
}

afectat de coroziune. Corp parțial păstrat, afectat de coroziune. Vârf rupt (pl. 8/3).

4. Piron (fragmentar); Lp $=6,7 \mathrm{~cm}$. Fier oxidat, corodat. Nerestaurat. Cap rupt. Corp parțial păstrat, puternic afectat de coroziune. Vârf rupt (pl. 8/4).

5. Piron (fragmentar); $\mathrm{Lp}=4,9 \mathrm{~cm}$. Fier oxidat, corodat. Nerestaurat. Cap rotund. Corp parțial păstrat, afectat de coroziune, cu secțiune patrulateră. Vârf rupt (pl. 8/5).

6. Piron (fragmentar); $\mathrm{Lp}=2 \mathrm{~cm}$. Fier oxidat, corodat. Nerestaurat. Cap rotund, afectat de coroziune. Corp parțial păstrat, cu secțiune pătrată: 0,5 cm. Vârf rupt (pl. 8/6).

7. Cui (fragmentar); $\mathrm{Lp}=3,5 \mathrm{~cm}$. Fier oxidat, corodat. Nerestaurat. Cap rupt. Corp parțial păstrat, afectat de coroziune, cu secțiune pătrată: 0,5 cm. Vârf rupt (pl. 8/7).

\section{271 (pl. 9) ${ }^{35}$ ardere pe loc}

Localizare: situat în partea de nord, în interiorul celei de-a doua faze de construcție a incintei, S 010901194 careul 17, carourile $1-2 / \mathrm{c}-\mathrm{f}$.

Dimensiuni: $\mathrm{L}=2,40 \mathrm{~m} ; \mathrm{l}=1,50 \mathrm{~m}$; $\mathrm{Li}=1,84 \mathrm{~m} ; \mathrm{li}=0,64 \mathrm{~m}$; Ad = 0,58 m; Ad.a $=0,85 \mathrm{~m}$.

\section{Orientare: NV-SE.}

Groapă de formă rectangulară, prevăzută cu treaptă ${ }^{36}$, pe laturile lungi; pereții gropii sunt arşi (arsură continuă cu o grosime de 0,05-0,08 m), uşor înclinați; partea inferioară a gropii este plată. Complexul a fost acoperit cu dale de piatră (cu dimensiuni cuprinse între 0,74 ×0,50 $\times$ $0,15 \mathrm{~m}$ şi $0,60 \times 0,25 \times 0,10 \mathrm{~m})$, dar datorită unei intervenții ulterioare ( $G$ 2) acestea au fost antrenate în interiorul gropii sepulcrale.

Sedimentul de umplutură al gropii sepulcrale, de culoare galben-maroniu, conține pigmenți de cărbune şi pământ ars de culoare roşie. Resturile cremației sunt observate doar în jumătatea de est a gropii; se constată astfel, un tratament intermediar de

\footnotetext{
35 Adâncimile figurate pe desen sunt de la ax.

${ }^{36}$ Datorită zidului de nord (Z 5).
} 
separare a oaselor calcinate de resturile rugului. Perturbarea antropică $\left(\begin{array}{ll}G & 2\end{array}\right)^{37}$ interferează nivelul de reziduuri ale cremației şi distruge parțial latura de sud a mormântului.

Inventar: ceramică: un urcior, o cupă, un opaiț, un vas nedeterminabil ca formă; sticlă: un unguentarium; obiecte din metal: trei scoabe, un piron, patru cuie, 54 ținte (concentrate în colțul de nord-vest al gropii mormântului), două obiecte neidentificabile.

1. Urcior nedeterminabil ca tip (fragmentar, se păstrează 14 fragmente din corp cu dimensiuni cuprinse între 1-6 cm); Pastă RM 3; ardere primară uniformă; puternic afectată de aciditatea solului. Corp globular (?).

2. Cupă nedeterminabilă ca tip (fragmentară, se păstrează două fragmente din bază şi mici fragmente din corp); Pastă RM 12; ardere primară uniformă; puternic afectată de aciditatea solului. Bază inelară.

3. Opaiț Loeschcke X (întregit); L = 9,6 cm; l = $6 \mathrm{~cm} ; \mathrm{h}=3,6 \mathrm{~cm}$. Pastă RM 5; ardere primară uniformă; ardere secundară pe capac şi rezervor; afectată de aciditatea solului. Disc neted, rotund, cu un orificiu de alimentare în centru, delimitat de bordură printr-un cordon proeminent, care se îndreaptă spre cioc şi formează un canal, prevăzut cu un mic orificiu de aerisire. Bordura lată, înclinată, este prevăzută cu trei butoni dispuşi aproximativ simetric. Cioc alungit, rotunjit, cu un arzător în formă de vârf de săgeată arondat. Rezervor tronconic (pl. 10/3).

4. Vas nedeterminabil ca formă (fragmentar, se păstrează un fragment din corp cu dimensiuni de 5,5 × 4,5 cm); Pastă RM 10; ardere primară uniformă; urme de ardere secundară la exterior; afectată de aciditatea solului.

5. Unguentarium (fragmentar, lipsesc fragmente din corp, gât şi buză); db = $5 \mathrm{~cm}$; hp = 7,8 cm. Sticlă subțire, suflată liber, verzuie, transparentă, cu mici bule de aer şi striaţii în compoziție, irizată (pl. 10/5).

6. Scoabă (întreagă); L = $7 \mathrm{~cm}$. Fier oxidat, corodat. Nerestaurată. Bară cu secțiunea dreptunghiulară: $1,4 \times 0,5$ cm. Se păstrează ambele cuie, uşor îndoite la capete: Lcui 1 = 1,5 cm; Lcui 2 = 1,5 cm (pl. 10/6).

\footnotetext{
${ }^{37}$ Vezi infra, intervenții asupra monumentului, p.105.
}

7. Scoabă (fragmentară); Lp = 5,5 cm. Fier oxidat, corodat. Nerestaurată. Bară puternic afectată de coroziune. Un cui rupt, altul parțial păstrat: Lcui = 1 cm (pl. 10/7).

8. Scoabă (fragmentară); Lp = 1,3 cm. Fier oxidat, puternic corodat. Nerestaurată. Bară parțial păstrată, puternic afectată de coroziune. Un cui rupt, celălalt parțial păstrat: Lcui = 2,1 cm (pl. 10/8).

9. Piron (fragmentar); Lp = 3,4 cm. Fier oxidat, corodat. Nerestaurat. Cap rupt. Corp parțial păstrat, îndoit spre partea inferioară, puternic afectat de coroziune. Vârf rupt (pl. 10/9).

10. Cui (fragmentar); Lp $=4,5 \mathrm{~cm}$. Fier oxidat, corodat. Nerestaurat. Se păstrează un fragment din corp, puternic afectat de coroziune (pl. 10/10).

11. Cui (fragmentar); $\mathrm{Lp}=4,4 \mathrm{~cm}$. Fier oxidat, corodat. Nerestaurat. Cap rotund, puternic afectat de coroziune. Corp drept, puternic afectat de coroziune. Vârf rupt (pl. 10/11).

12. Cui (fragmentar); Lp $=3,8 \mathrm{~cm}$. Fier oxidat, corodat. Nerestaurat. Cap rupt. Corp puternic afectat de coroziune. Vârf rupt (pl. 10/12).

13. Cui (fragmentar); $\mathrm{Lp}=2,9 \mathrm{~cm}$. Fier oxidat, corodat. Nerestaurat. Cap rupt. Corp parțial păstrat, cu secțiune dreptunghiulară: 0,4 × 0,3 cm. Vârf rupt (pl. 10/13).

14. Țintă (întreagă); L = 2,8 cm. Fier oxidat, corodat. Nerestaurată. Cap în formă de vârf de cupolă, puternic afectat de coroziune. Corp uşor îndoit, afectat de coroziune. Vârf îndoit (pl. 10/14).

15. Țintă (întreagă); L = $2 \mathrm{~cm}$. Fier oxidat, corodat. Nerestaurată. Cap rotund, puternic afectat de coroziune. Corp îndoit, afectat de coroziune. Vârf îndoit (pl. 10/15).

16. Țintă (fragmentară); Lp = 2,7 cm. Fier oxidat, corodat. Nerestaurată. Cap rotund, puternic afectat de coroziune. Corp puternic afectat de coroziune. Vârf rupt (pl. 10/16).

17. Țintă (fragmentară); Lp = 2,3 cm. Fier oxidat, corodat. Nerestaurată. Cap rotund, bombat. Corp puternic afectat de coroziune. Vârf rupt (pl. 10/17).

18. Țintă (fragmentară); Lp = 2,1 cm. Fier oxidat, corodat. Nerestaurată. Cap rotund, 
bombat. Corp puternic afectat de coroziune. Vârf rupt (pl. 10/18).

19. Țintă (fragmentară); $L p=2 \mathrm{~cm}$. Fier oxidat, corodat. Nerestaurată. Cap rotund, afectat de coroziune. Corp puternic afectat de coroziune. Vârf rupt (pl. 10/19).

20. Țintă (fragmentară); Lp $=2 \mathrm{~cm}$. Fier oxidat, corodat. Nerestaurată. Cap rotund, bombat. Corp puternic afectat de coroziune. Vârf rupt (pl. 10/20).

21. Țintă (fragmentară); $L p=2 \mathrm{~cm}$. Fier oxidat, corodat. Nerestaurată. Cap rotund, bombat, puternic afectat de coroziune. Corp afectat de coroziune. Vârf rupt (pl. 10/21).

22. Țintă (fragmentară); $L p=2 \mathrm{~cm}$. Fier oxidat, corodat. Nerestaurată. Cap rotund, puternic afectat de coroziune. Corp afectat de coroziune. Vârf rupt (pl. 10/22).

23. Țintă (fragmentară); Lp = 1,9 cm. Fier oxidat, corodat. Nerestaurată. Cap rotund, bombat, afectat de coroziune. Corp afectat de coroziune. Vârf rupt (pl. 10/23).

24. T,intă (fragmentară); $L p=1,9 \mathrm{~cm}$. Fier oxidat, corodat. Nerestaurată. Cap rotund, puternic afectat de coroziune. Corp uşor îndoit, cu secțiune circulară: 0,2 cm. Vârf rupt (pl. 10/24).

25. Tintă (fragmentară); $L p=1,9 \mathrm{~cm}$. Fier oxidat, corodat. Nerestaurată. Cap puternic afectat de coroziune. Corp parțial păstrat. Vârf rupt (pl. 10/25).

26. Țintă (fragmentară); $L p=1,9 \mathrm{~cm}$. Fier oxidat, corodat. Nerestaurată. Cap rotund, bombat. Corp puternic afectat de coroziune, îndoit spre partea inferioară, cu secțiune pătrată: $0,3 \mathrm{~cm}$. Vârf rupt (pl. 10/26).

27. Țintă (fragmentară); $\mathrm{Lp}=1,8 \mathrm{~cm}$. Fier oxidat, corodat. Nerestaurată. Cap rotund, puternic afectat de coroziune. Corpul şi vârful rupte. (pl. 10/27)

28. Țintă (fragmentară); Lp $=1,8 \mathrm{~cm}$. Fier oxidat, corodat. Nerestaurată. Cap rotund, bombat. Corp cu secțiune pătrată: $0,3 \mathrm{~cm}$. Vârf rupt (pl. 10/28).

29. Țintă (fragmentară); $L p=1,7 \mathrm{~cm}$. Fier oxidat, corodat. Nerestaurată. Cap în formă de vârf de cupolă. Corp parțial păstrat, puternic afectat de coroziune. Vârf rupt (pl. 10/29).

30. Țintă (fragmentară); $L p=1,7 \mathrm{~cm}$. Fier oxidat, corodat. Nerestaurată. Cap rupt. Corp puternic afectat de coroziune. Vârf rupt (pl. 10/30).

31. Țintă (fragmentară); $L p=1,7 \mathrm{~cm}$. Fier oxidat, corodat. Nerestaurată. Cap rotund, bombat, afectat de coroziune. Corp puternic afectat de coroziune. Vârf rupt (pl. 11/31).

32. Țintă (fragmentară); $L p=1,7 \mathrm{~cm}$. Fier oxidat, corodat. Nerestaurată. Cap rotund, bombat, puternic afectat de coroziune. Corp parțial păstrat. Vârf rupt (pl. 11/32).

33. Țintă (fragmentară); $L p=1,7 \mathrm{~cm}$. Fier oxidat, corodat. Nerestaurată. Cap rotund, puternic afectat de coroziune. Corp parțial păstrat. Vârf rupt (pl. 11/33).

34. Țintă (fragmentară); $L p=1,6 \mathrm{~cm}$. Fier oxidat, corodat. Nerestaurată. Cap rupt. Corp puternic afectat de coroziune. Vârf rupt (pl. 11/34).

35. Țintă (fragmentară); Lp = 1,6 cm. Fier oxidat, corodat. Nerestaurată. Cap rotund, bombat, puternic afectat de coroziune. Corpul şi vârful rupte (pl. 11/35).

36. Țintă (fragmentară); $L p=1,5 \mathrm{~cm}$. Fier oxidat, corodat. Nerestaurată. Cap rotund, bombat, puternic afectat de coroziune. Corpul şi vârful rupte (pl. 11/36).

37. Țintă (fragmentară); $L p=1,5 \mathrm{~cm}$. Fier oxidat, corodat. Nerestaurată. Cap rotund, afectat de coroziune. Corp parțial păstrat, puternic afectat de coroziune. Vârf rupt (pl. 11/37).

38. Țintă (fragmentară); $L p=1,5 \mathrm{~cm}$. Fier oxidat, corodat. Nerestaurată. Cap rotund, bombat, afectat de coroziune. Corp uşor îndoit. Vârf rupt (pl. 11/38).

39. Țintă (fragmentară); $L p=1,5 \mathrm{~cm}$. Fier oxidat, corodat. Nerestaurată. Cap rotund, puternic afectat de coroziune. Corp parțial păstrat, afectat de coroziune. Vârf rupt (pl. 11/39).

40. Țintă (fragmentară); $L p=1,5 \mathrm{~cm}$. Fier oxidat, corodat. Nerestaurată. Cap rotund, bombat, puternic afectat de coroziune. Corp parțial păstrat, afectat de coroziune. Vârf rupt (pl. 11/40).

41. Țintă (fragmentară); $L p=1,5 \mathrm{~cm}$. Fier oxidat, corodat. Nerestaurată. Cap rotund, bombat. Corp parțial păstrat, afectat de coroziune. Vârf rupt (pl. 11/41).

42. Țintă (fragmentară); $L p=1,4 \mathrm{~cm}$. Fier oxidat, corodat. Nerestaurată. Cap rotund, 
bombat, puternic afectat de coroziune. Corp parțial păstrat, cu secțiune pătrată: 0,3 cm. Vârf rupt (pl. 11/42).

43. Țintă (fragmentară); Lp = 1,4 cm. Fier oxidat, corodat. Nerestaurată. Se păstrează un fragment puternic afectat de coroziune (pl. 11/43).

44. Tintă (fragmentară); Lp = 1,4 cm. Fier oxidat, corodat. Nerestaurată. Cap rotund, puternic afectat de coroziune. Corpul şi vârful rupte (pl. 11/44).

45. Tiintă (fragmentară); Lp = 1,4 cm. Fier oxidat, corodat. Nerestaurată. Cap rotund, puternic afectat de coroziune. Corp parțial păstrat, afectat de coroziune. Vârf rupt (pl. 11/45).

46. Țintă (fragmentară); Lp = 1,3 cm. Fier oxidat, corodat. Nerestaurată. Cap rotund, bombat, afectat de coroziune. Corp parțial păstrat, afectat de coroziune. Vârf rupt (pl. 11/46).

47. Țintă (fragmentară); Lp = 1,2 cm. Fier oxidat, corodat. Nerestaurată. Cap rotund, bombat. Corp parțial păstrat. Vârf rupt (pl. 11/47).

48. Țintă (fragmentară); Lp = 1,2 cm. Fier oxidat, corodat. Nerestaurată. Cap rotund, bombat. Corpul şi vârful rupte (pl. 11/48).

49. Ţintă (fragmentară); Lp = 1,2 cm. Fier oxidat, corodat. Nerestaurată. Cap rotund, bombat. Corpul şi vârful rupte (pl. 11/49).

50. Tiintă (fragmentară); Lp = 1,1 cm. Fier oxidat, corodat. Nerestaurată. Cap rotund, bombat, puternic afectat de coroziune. Corpul şi vârful rupte (pl. 11/50).

51. Tintă (fragmentară); Lp = 1,1 cm. Fier oxidat, corodat. Nerestaurată. Cap rotund, afectat de coroziune. Corp parțial păstrat, puternic afectat de coroziune. Vârf rupt (pl. 11/51).

52. Tintă (fragmentară); Lp = $1 \mathrm{~cm}$. Fier oxidat, corodat. Nerestaurată. Cap rotund, afectat de coroziune. Corp parțial păstrat, puternic afectat de coroziune. Vârf rupt (pl. 11/52).

53. Tintă (fragmentară); Lp = $1 \mathrm{~cm}$. Fier oxidat, corodat. Nerestaurată. Cap rotund, puternic afectat de coroziune. Corpul şi vârful rupte (pl. 11/53).

54. Tintă (fragmentară); Lp = $1 \mathrm{~cm}$. Fier oxidat, corodat. Nerestaurată. Cap rotund, bombat, puternic afectat de coroziune. Corpul şi vârful rupte (pl. 11/54).

55. Țintă (fragmentară); Lp $=1 \mathrm{~cm}$. Fier oxidat, corodat. Nerestaurată. Cap rotund, bombat, puternic afectat de coroziune. Corpul şi vârful rupte (pl. 11/55).

56. Tintă (fragmentară); Lp = $1 \mathrm{~cm}$. Fier oxidat, corodat. Nerestaurată. Cap rotund, bombat. Corpul şi vârful rupte (pl. 11/56).

57. Tintă (fragmentară); Lp =0,9 cm. Fier oxidat, corodat. Nerestaurată. Cap rotund, bombat, afectat de coroziune. Corp parțial păstrat, cu secțiune rectangulară. Vârf rupt (pl. 11/57).

58. Țintă (fragmentară); Lp =0,9 cm. Fier oxidat, corodat. Nerestaurată. Cap rotund, puternic afectat de coroziune. Corpul şi vârful rupte (pl. 11/58).

59. Țintă (fragmentară); Lp = 0,9 cm. Fier oxidat, corodat. Nerestaurată. Cap rotund, puternic afectat de coroziune. Corpul şi vârful rupte (pl. 11/59).

60. Țintă (fragmentară); Lp = 0,5 cm. Fier oxidat, corodat. Nerestaurată. Cap rotund, bombat, puternic afectat de coroziune. Corpul şi vârful rupte (pl. 11/60).

61. Două ținte (întregi); Lț1 = 2,1 cm; Lț2 $=1,6 \mathrm{~cm}$. Fier oxidat, corodat. Nerestaurate. Cele două piese sunt lipite în urma temperaturii ridicate, degajată în timpul procesului de cremație a defunctului. T,1: Cap rotund, afectat de coroziune. Corp îndoit spre partea inferioară. Vârf tocit. Ț2: Cap rotund, bombat. Corp uşor îndoit spre partea inferioară. Vârf tocit (pl. 11/61).

62. Două ținte (fragmentare); Lpț1 = 1,8 cm; Lpț2 = 1,6 cm. Fier oxidat, corodat. Nerestaurate. Cele două piese sunt lipite în urma temperaturii ridicate, degajată în timpul procesului de cremație a defunctului. Ț1: Cap puternic afectat de coroziune. Corp cu secțiune circulară. Vârf rupt. Ț2: Capul şi corpul puternic afectate de coroziune. Vârf rupt (pl. 11/62).

63. Două ținte (fragmentare); Lpț1 = 1,3 cm; Lpț2 = 1,2 cm. Fier oxidat, corodat. Nerestaurate. Cele două piese sunt lipite în urma temperaturii ridicate, degajată în timpul procesului de cremație a defunctului. Ț1: Cap rotund, bombat. Corp puternic afectat de coroziune, îndoit spre partea inferioară. Vârf rupt. Ț2: Cap rotund. Corpul şi vârful rupte (pl. 11/63).

64. Două ținte (fragmentare); Lpț1 = 1,3 cm; Lpț2 = $1 \mathrm{~cm}$. Fier oxidat, corodat. Nerestaurate. Cele două piese sunt lipite în urma temperaturii ridicate, degajată în timpul 
procesului de cremație a defunctului. Ț1: Cap rotund. Corp îndoit spre partea inferioară. Vârf rupt. Ț2: Cap rotund, bombat. Corpul şi vârful rupte (pl. 11/64).

65. Obiect neidentificabil (fragmentar); Lp = 5,4 cm. Fier oxidat, corodat. Nerestaurat. Se păstrează două fragmente puternic afectate de coroziune (pl. 11/65).

66. Obiect neidentificabil (fragmentar); $\mathrm{Lp}=2,5 \mathrm{~cm}$. Fier oxidat, corodat. Nerestaurat. Se păstrează un fragment puternic afectat de coroziune (pl. 11/66).

\section{Intervenții asupra monumentului (pl.} 1, pl. 2)

Asupra monumentului au avut loc patru intervenții antropice, care afectează atât gropile sepulcrale, cât şi zidurile ${ }^{38}$. De asemenea, perturbări antropice recente ${ }^{39}$ afectează parțial complexul M 270. Toate perturbările antropice au fost făcute în acelaşi moment $^{40}$.

G1 - groapă de intervenție de formă aproximativ circulară în plan şi conică în secțiunea transversală.

Localizare: S 010901194 careul 17, caroul 5/f, şi careul 18, caroul 5/e.

Dimensiuni: diametrul maxim la partea superioară $1,56 \mathrm{~m}$; diamentrul în partea inferioară 0,20 m ; adâncimea la care a apărut 0,08 m; adâncimea maximă 0,90 m.

Din punct de vedere stratigrafic s-au putut observa două faze de umplere a gropii:

- prima fază este constituită dintr-un sediment maroniu, conține pietre de dimensiuni medii, fragmente de sol ars de culoare roşiatică. În acest sediment se observă o lentilă de cărbune pe o lățime de $0,16 \mathrm{~m}$; această lentilă nu conține resturi calcinate.

\footnotetext{
38 Datorită perturbărilor antropice Z1 şi Z4 sunt puternic afectate.

${ }^{39}$ Lucrările agricole.

${ }^{40}$ Gropile de intervenție sunt practicate de la acelaşi nivel.
}

— a doua fază este constituită dintr-un sediment de culoare cenuşiu-negricios (asemănător cu nivelul 2), sediment rezultat al colmatării.

G2 — groapă de intervenție de formă aproximativ circulară în plan şi conică în secțiunea transversală.

Localizare: S 010901194 careul 17, caroul 1/a.

Dimensiuni: diametrul maxim la partea superioară $1,20 \mathrm{~m}$; diamentrul în partea inferioară $0,14 \mathrm{~m}$; adâncimea la care a apărut 0,10 m; adâncimea maximă 0,62 m.

Din punct de vedere stratigrafic s-au putut observa două faze de umplere a gropii:

- prima fază este constituită dintr-un sediment maroniu, conține pietre de dimensiuni medii, fragmente de sol ars de culoare cărămizie. În acest sediment se observă o lentilă de cărbune pe o lățime de $0,54 \mathrm{~m}$.

- a doua fază este constituită dintr-un sediment de culoare cenuşiu-negricios (asemănător cu nivelul 2), sediment rezultat al colmatării.

G3 - groapă de intervenție de formă aproximativ circulară în plan şi conică în secțiunea transversală.

Localizare: S 010901194 careul 17 caroul 5/e

Dimensiuni: diametrul maxim la partea superioară $0,66 \mathrm{~m}$; diamentrul în partea inferioară $0,10 \mathrm{~m}$; adâncimea la care a apărut 0,10 m; adâncimea maximă 0,38 m.

Din punct de vedere stratigrafic nu a fost surprinsă decât o fază de umplere:

- sediment de culoare cenuşiunegricios (asemănător cu nivelul 2), sediment rezultat al colmatării, conține pietre de dimensiuni medii, fragmente de sol ars de culoare roşiatică. 
G4 - groapă de intervenție de formă aproximativ circulară în plan şi conică în secțiunea transversală.

Localizare: S 010901194 careul 18, carourile 3/b-c.

Dimensiuni: diametrul maxim la partea superioară $2,00 \mathrm{~m}$; diamentrul în partea inferioară $0,20 \mathrm{~m}$; adâncimea la care a apărut $0,10 \mathrm{~m}$; adâncimea maximă 0,70 m.

Din punct de vedere stratigrafic nu a fost surprinsă decât o fază de umplere:

- sediment de culoare cenuşiunegricios (asemănător cu nivelul 2), sediment rezultat al colmatării, conține pietre de dimensiuni medii, fragment ceramic, pigmenți de cărbune.

\section{Cronologia relativă}

În concluzie, incinta funerară, care face obiectul studiului nostru, are două faze de funcționare, trei înmormântări şi patru perturbări antropice.

Între cele două faze de construcție există atât diferențe privind gradul de prelucrare a materialului litic utilizat în ridicarea elevației, cât şi la nivelul materiei prime folosite $^{41}$. În prima etapă de construcție au fost utilizate blocuri de piatră de dimensiuni mari $(1,20 \times 1,00 \times 0,60 \mathrm{~m}$ şi $1,00 \times 0,80 \times 0,40 \mathrm{~m}$ ), foarte puțin prelucrate sau deloc, în timp ce în faza a doua, blocurile de piatră sunt prelucrate şi au dimensiuni cuprinse între $0,80 \times 0,60 \times 0,40 \mathrm{~m}$ şi $0,60 \times$ $0,40 \times 0,20 \mathrm{~m}$.

Zidurile din prima fază se păstrează pe înălțimea de două sau trei asize.

În cazul tuturor celor cinci trasee (Z1, Z2a, Z3, Z4a, Z5) este vizibilă urma şanțului de fundație, iar modalitatea de realizare a elevației a ținut cont de configurația antică a terenului. Astfel, dalele de piatră au fost aşezate progresiv, de la NE spre SV.

41 În prima fază au fost folosite cu predilecție conglomerate, iar în faza a doua s-au utilizat gresii şi andezite.
M 268 corespunde primei faze, în timp ce extinderea incintei este legată de necesitatea măririi spațiului funerar utilizat pentru cea de-a doua înmormântare, M 271. M 268 se află într-o relaţie de posterioritate față de prima fază de funcționare a incintei ${ }^{42}$.

Ultima înmormântare, M 270, utilizează spațiul descris de prima fază, amplasamentul său fiind condiţionat de prezența înmormântărilor anterioare. Amenajarea celei de-a doua faze este realizată într-un moment apropiat celei de-a doua înmormântări (M 271).

M 271, reprezintă a doua înmormântare şi este posterioară primei faze de construcție a incintei, latura de sud a gropii sepulcrale fiind amenajată pe zidul de nord (Z5) şi anterioară celei de-a doua fază de funcționare. Latura de nord a mormântului este suprapusă de Z1 din faza a doua de constructie a incintei. Extinderea incintei a fost probabil dictată de nevoia extinderii spațiului funerar în condițiile amenajării $\mathrm{M}$ 271.

M 270 reprezintă ultima înmormântare, deşi spațial groapa sepulcrală se încadrează în perimetrul descris de prima fază a incintei. Din punct de vedere stratigrafic este vizibil faptul că acest mormânt este amenajat ulterior M 271. Aceste repere cronologice sunt coroborate cu datele altimetrice. Astfel, diferența altimetrică între prima şi ultima înmormântare este de 0,80 m, în timp ce $M$ 270 şi M 271 au fost surprinse de la acelaşi nivel. Un alt argument care justifică cronologia relativă stabilită, este acela că, pietrele din construcția Z2 şi Z4 prezintă urme de ardere secundară în dreptul M 270, ceea ce ne îndreptățeşte să credem că, la momentul amenajării gropii M 270, incinta funcționa în faza a II-a. De asemenea, M 268 şi M 271 se suprapun în proporție de 15\%,

\footnotetext{
42 Această concluzie se bazează pe faptul că lentile de pământ ars, care țin de acest complex, au fost observate la intersecția dintre cele două faze de construcție şi, de asemenea, pietre din zidul de sud (Z3) prezintă urme de ardere.
} 
(latura de nord a complexului cu sigla M 268 şi respectiv latura de sud a complexului $\mathrm{M}$ 270).

Incinta funerară analizată are cele mai apropiate analogii, ca modalitate de construcție, la Alburnus Maior. Astfel, în cele cinci necropole şi două zone funerare cercetate până acum în acest sit, au fost identificate opt asemenea incinte funerare rectangulare (în necropola de incinerație de la Tăul Găuri $\mathrm{Hop}^{43}$, zona funerară Carpeni ${ }^{44}$; în necropola de incinerație din Țarina ${ }^{45}$, în necropola de la Tăul Secuilor-Pârâul Porcului ${ }^{46}$ ). Toate sunt amenajări rectangulare din piatră legată cu pământ, în interiorul cărora au fost identificate unul sau mai multe morminte de incinerație, patru dintre ele având ultima asiză sub formă de chaperon.

Asemenea construcții funerare au fost semnalate şi investigate în provincia Dacia Superior: la Cincişs ${ }^{47}$ (cu două compartimentări),

43 CCA 2002 (2003), 104-105, două incinte funerare (una cercetată parțial), iar alta rectangulară (cu dimensiunile de 8,20 × 7,60 × 7,60 × 6,20 m); are două faze de funcționare şi patru morminte de incinerație (în curs de cercetare); Moga et alii 2003, 205, 226, fig. 12, 248, fig. 3, o incintă funerară, de formă patrulateră cu laturile aproximativ egale, cu latura de $5 \mathrm{~m}$, cu un mormânt de incinerație.

${ }^{44}$ Rusu-Bolindeț et alii 2003, 389, 406, fig. 10, o incintă funerară rectangulară cercetată parțial, în interiorul căreia au fost descoperite două morminte de incinerație, ambele complexe dispun de câte o amenajare anterioară sub forma unui ring de piatră.

45 CCA 2004 (2005), 298, o incintă funerară rectangulară cu dimensiunile de $7,20 \times 6,85 \times 6,25 \times 5,60 \mathrm{~m}$, ultima asiză este realizată utilizând blocuri de piatră de forma unui chaperon, cu un mormânt de incineratie; CCA 2005 (2006), 298, o incintă patrulateră (în curs de cercetare), cu un mormânt de incineratie.

46 O incintă funerară cercetată de un colectiv al Muzeului Național de Istorie a României (vezi nota 2) în campania 2005, material în curs de prelucrare; Crăciun, Moga 2003, 37, o incintă funerară rectangulară cu laturile 7,80 × 5,20 m, ultima asiză este realizată utilizând blocuri de piatră de forma unui chaperon, cercetată parțial.

${ }^{47}$ Incintă funerară de formă rectangulară, cu dimensiunile de $10,80 \times 9,25 \mathrm{~m}$; vezi Floca, Valea 1965, 163-194. în interiorul cărora au fost identificate patru morminte $^{48}$, la Ulpia Traiana Sarmizegetusa, în necropola de vest a fost cercetată o incintă rectangulară ${ }^{49}$. De asemenea, astfel de construcții funerare au fost cercetate în cadrul necropolei de est a aceluiaşi sit ${ }^{50}$.

Astfel de construcții funerare au fost cercetate în mai multe provincii occidentale ale imperiului: Pannonia Inferior (Matrica ${ }^{51}$ ), Gallia Cisalpina (Boretto $^{52}$, incintă funerară rectangulară ${ }^{53}$ ), Gallia Belgica (WadernOberlöstern $^{54}$, incintă funerară rectangulară ${ }^{55}$ cu platformă pentru monument funerar, în interiorul căreia a fost identificat un mormânt de incinerație), Gallia Celtica (BiberistSpitalhof $^{56}$, incintă funerară cu două faze ${ }^{57}$, în interiorul căruia au fost identificate un mormânt de tip bustum şi o urnă) etc.

În ceea ce priveşte modalitatea de înmormântare a defuncților analogii se întâlnesc în toate provinciile romane, cu o frecvență mai ridicată în cele subsumate termenului generic de Illyricum: Dacia Superior (Alburnus Maior ${ }^{58}$, Boteş/Corabia $^{59}$, Apulum ${ }^{60}$, Muncelu-Brad ${ }^{61}$, Cinciş $^{62}$, Ulpia Traiana Sarmizegetusa ${ }^{63}$, Tibiscum $\left.^{64}\right)$; Dacia Inferior $\quad\left(\right.$ Romula $\left.^{65}\right)$;

\footnotetext{
48 Trei morminte de incinerație şi unul cu ritul incert.

49 Allen 1993, 397-400; CCA 2002 (2003), 267-269, în curs de cercetare.

50 Simion et alii 2004, 84, nota 162. Într-una dintre incinte au fost identificate patru morminte de incinerație.

51 Topal 2000, 199, fig. 20.2.

52 Ortalli 1998, 63, fig. 11 (incinta funerară a Concordiilor).

${ }^{53} \mathrm{Cu}$ dimensiunile de 10,8 × 9,2 m.

${ }^{54}$ Abegg-Wigg 2000, 113, 12.2 .

${ }^{55} \mathrm{Cu}$ dimensiunile de $6 \times 4,9 \mathrm{~m}$.

${ }^{56}$ Schucany 2000, 118-124, fig. 13/3, 13/4.

${ }^{57}$ Cu dimensiunile de $9 \times 9 \mathrm{~m}$.

58 Necropola de incinerație de la Tăul Găuri Hop (Moga et alii 2003, 193-251; CCA 2002 (2003), 104-105), Necropola de incinerație de la Tăul Corna (Alburnus Maior III), Necropola de incinerație de la Jig-Piciorag (CCA 2003 (2004), 262-264), T, Tarina (CCA 2003 (2004), 262-264; CCA 2004 (2005), 298-313; CCA 2005 (2006), 297-298).

59 Floca 1936-1940, 160-173.

60 Protase 1974, 141-159.

${ }^{61}$ Rusu 1979, 219.

62 Floca, Valea 1965, 171-192.

63 Allen 1993, 398.

64 Petrowsky 1979, 205-210.

65 Babeş 1970, 177-180.
} 
Pannonia Inferior (Matrica ${ }^{66}$, Aquincum ${ }^{67}$ ); Moesia Superior (Viminacium $^{68}$, Kosmaj (Guberavat) $^{69} ;$ Ulpiana $^{70}$, Matka $^{71}$, Mala Kopašnica $^{72}$, Naissus ${ }^{73}$, Skopje ${ }^{74}$, Velika Grabovnika $^{75}$, Boljetin ${ }^{76}$, Zuto Brdo $^{77}$ ); Dalmatia $\quad$ Docle $^{78}$, Stup ${ }^{79}$, Rogatica ${ }^{80}$, Komini $^{81}$ ); Gallia Narbonesis (Lyon ${ }^{82}$, SaintPaul-Trois-Chateâux ${ }^{83}$ ); Gallia Celtica (BiberistSpitalhof $^{84}$; Britannia (Londinium ${ }^{85}$ ) etc.

Aceste complexe de incinerație sunt datate, în marea lor majoritate, în secolul al II p.Chr.

Datorită intervențiilor ulterioare suferite de-a lungul timpului de ansamblul funerar, nu a fost posibilă o analiză în detaliu a poziţionării şi distribuției spaţiale a inventarului funerar în cele trei morminte analizate mai sus ${ }^{86}$.

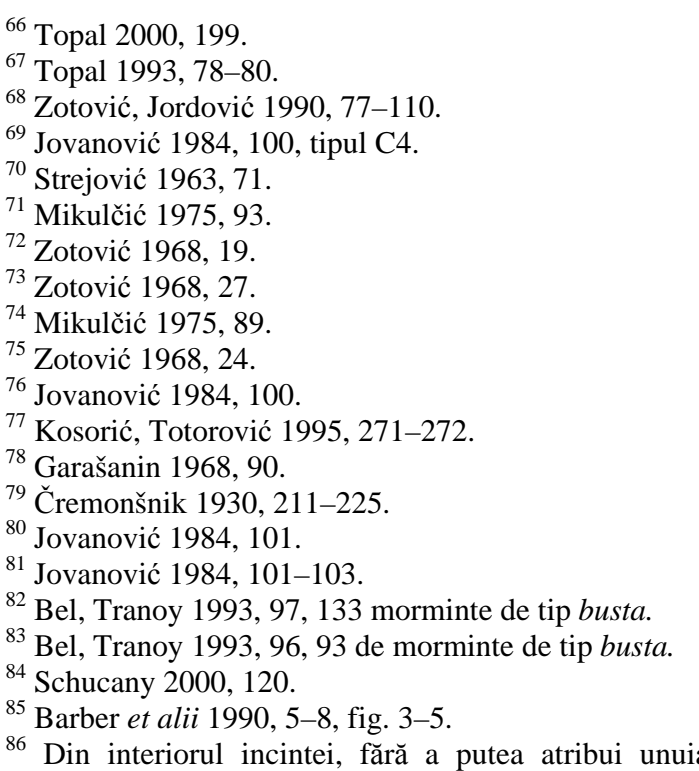

${ }^{86}$ Din interiorul incintei, fără a putea atribui unuia
dintre mormintele M 268, M 270 sau M 271, sau fără a putea menționa utilizarea lor în cadrul vreunei secvențe a ritualului de înmormântare, au fost recoltate şapte obiecte prezentate mai jos (pl. 12):

1. Urcior nedeterminabil ca tip (fragmentar, se păstrează trei fragmente din toartă cu dimensiuni cuprinse între 1-2,7 cm); din dărâmătura $\mathrm{Z4;} a=0,60$ m; Pastă RM 5; ardere primară uniformă; uşor afectată de aciditatea solului. Toartă necanelată.

2. Oală nedeterminabilă ca tip (fragmentară, se păstrează un fragment de bază cu corp şi 12 din corp); din dărâmătura Z4b; a = 0,35 m; db = 6,8 cm. Pastă RM 1 ; ardere primară inegală; urme de ardere secundară; uşor afectată de aciditatea solului. Bază dreaptă.

3. Capac nedeterminabil ca tip (fragmentar, se păstrează un fragment de buton $\mathrm{cu}$ pereți); din dărâmătura Z2b; a = 0,45 m; dbuton = 4,2 cm; hp = 3,2
Inventarul celor trei morminte analizate mai sus este constituit din obiecte din ceramică (urcioare, turibula, oale, cupe, opaițe), obiecte din sticlă (un unguentarium, o mărgea) şi obiecte din fier (un topor, o cheie, scoabe, piroane, cuie şi ținte). Cea mai mare parte a obiectelor ceramice prezintă un grad mare de fragmentaritate, atât datorită caracteristicilor legate probabil de specificul ritului şi ritualului funerar din perioada romană (arderea pe rug a ofrandelor, depunerea în context funerar imediat după momentul cremației), cât şi datorită caracteristicilor pedologice specifice zonei Roşia Montană (aciditatea ridicată contribuie la deteriorarea artefactelor). De asemenea, intervențiile ulterioare asupra complexelor arheologice în discuție au contribuit la starea de fragmentaritate a ceramicii.

Pe baza argumentelor de mai sus, monumentul funerar analizat prezintă două faze de construcție şi funcționare: prima fază are dimensiunile de 4,50 × 3,90 m, iar în cea de-a doua fază de $6,00 \times 4,50 \mathrm{~m}$. Cea de-a doua fază reprezintă de fapt o extindere a incintei spre nord, cu $1,78 \mathrm{~m}$, motivată de necesitatea măririi spațiului funerar pentru a doua înmormântare.

cm. Pastă RM 1; ardere primară uniformă; puternic afectată de aciditatea solului. Buton scurt, neprofilat.

4. Capac nedeterminabil ca tip (fragmentar, se păstrează un fragment din buză şi cinci fragmente din pereți); din dărâmătura Z2b; a = 0,45 m; dg = 12,5 cm. Pastă RM 1; ardere primară uniformă; puternic afectată de aciditatea solului. Buză rotunjită, uşor înclinată spre interior.

5. Vas nedeterminabil ca formă (fragmentar, se păstrează două fragmente din toartă şi două din corp cu dimensiuni cuprinse între $2-4 \mathrm{~cm}$ ); din dărâmătura Z4; a = 0,60 m; Pastă RM 10; ardere primară uniformă; afectată de aciditatea solului. Toartă lată, canelată.

6. Vas nedeterminabil ca formă (fragmentar, se păstrează nouă fragmente din corp, cu dimensiuni cuprinse între 1,5-4 cm); din dărâmătura Z4; a = 0,60 m; Pastă RM 1; ardere primară uniformă; urme de ardere secundară pe interior.

7. T,iglă (fragmentară); din dărâmătura Z2b; a = 0,45 m; $5,5 \times 5 \times 2,4 \mathrm{~cm}$. Se păstrează un fragment din placă. 
Din punct de vedere al amplasamentului, monumentul este parte integrantă a necropolei de la Tăul Secuilor-Pârâul Porcului fiind construit în partea de nord vest a acesteia, într-o zonă cu o poziție dominantă în economia necropolei. Relativ la varianta de rit, mormintele din interiorul incintei nu reprezintă excepții față de restul complexelor funerare cercetate până în prezent în situl de la Roşia Montană. De aceea, stabilirea unei cronologii relative bazată exclusiv pe analiza tipologică a mormintelor este încă prematură, aceasta fiind posibilă numai în contextul realizării cartării şi analizei combinatorii a complexelor din întreaga necropolă.
$\mathrm{Nu}$ avem indicii epigrafice sau de orice altă natură care să ne confere informații legate de natura relațiilor dintre cei trei defuncți şi nici despre posibila origine sau încadrare etnică

Lipsa artefactelor cu putere de datare (ceramica de lux, terra sigilatta, ceramica cu glazură plombiferă, monede lizibile etc.) nu ne-au putut oferi criterii pentru o încadrare cronologică mai clară. Pe baza analogiilor şi ținând cont de datele generale din cadrul necropolei, de materialul existent, complexul se datează în secolul al II-lea p.Chr.

\section{ABREVIERI BIBLIOGRAFICE}

AISC - Anuarul Institutului de Studii Clasice, Cluj-Napoca.

Alburnus Maior I - Alburnus Maior, vol. I (coordonator Paul Damian), Bucureşti 2003.

Alburnus Maior III - Necropola romană de la Tăul Corna (coord. P. Damian), 2008 (sub tipar)

AMN - Acta Musei Napocensis, Cluj-Napoca.

Apulum - Acta Musei Apulensis, Alba-Iulia.

Banatica - Muzeul Județean Caraş-Severin, Reşița.

CCA 2002 (2003) - Cronica cercetărilor arheologice din România, campania 2002; a XXXVII-a Sesiune Națională de Rapoarte Arheologice, 2-6 iunie 2003, Covasna (București 2003).

CCA 2003 (2004) - Cronica cercetărilor arheologice din România, campania 2003; a XXXVIII-a Sesiune Națională de Rapoarte Arheologice, 26-29 mai, Cluj-Napoca (Bucureşti 2004).

CCA 2004 (2005) - Cronica cercetărilor arheologice din România, campania 2004; a XXXIX-a Sesiune Naţională de Rapoarte Arheologice, 25-28 mai, Jupiter-Mangalia (Bucureşti 2005).

CCA 2005 (2006) - Cronica cercetărilor arheologice din România, campania 2005; a XL-a Sesiune Națională de Rapoarte Arheologice, 31 mai-3 iunie 2006, Constanța (Bucureşti 2006).

Dacia N.S. - Dacia Nouvelle Série. Revue et d' Histoire Ancienne, Bucureşti.

God. CBI — Godišnjak za balkanološka istraživanja, Sarajevo.

GZM - Glasnik Zemaljskog Muzeja, Sarajevo.

Lescovački Zbornic- Lescovački Miscellany, Leskovac.

MCA - Materiale şi cercetări arheologice, Bucureşti.

Sargetia - Acta Musei Regionalis Devensis, Deva.

Starinar — Organ Srpskog Arheološkog Drustva, Beograd.

\section{BIBLIOGRAFIE}

Abegg-Wigg 2000 - Angelika Abegg-Wigg, A Roman Cemetery in the eastern Civitas Treverorum. Preliminary report on the excavations in Wadern-Oberlöstern in Northwestern Saarland (Germany), Burial, Society and Context in the Roman World, Oxford, 2000, 112-117.

Allen 1993 - T. Allen, Interim report on two seasons of excavations of burial enclosure in the east cemetery of Ulpia Traiana Sarmizegetusa, 1982-1984, în AMN 26-30, 1993, 1, 2, 397-400. 
Babeş 1970 - M. Babeş, Zu den Bestattunsgarten im nördlichen Flachgräberfeld von Romula. Ein Beitrag zur Grabtypologie des römischen Daziens, în Dacia N.S. 14, 1970, 167-207.

Barber et alli 1990 - B. Barber, D. Bowsher, K. Whittaker, Recent Excavations of a Cemetery of Londinium, Britannia 21, 1990, 1-12.

Bel, Tranoy 1993 - Valerie Bel, L. Tranoy, Note sur le busta dans le sud-est de la Gaule, Römerzeitlische Gräber als Quellen zu Religion, Bevölkerungsstruktur und Sozialgeschichte. Internationale Fachkonferenz vom 18.-20. Februar 1991 im Institut für Vor- und Frühgeschichte der Johannes Gutenberg-Universitat Mainz, Mainz, 1993, 95-110.

Crăciun, Moga 2003 - Cristina Crăciun, V. Moga, Cercetări de teren şi sondaje, în Alburnus Maior I, 2003, 33-42.

Čremonšnik 1930 - G. Čremonšnik, Nalazi iz rimskog doba na Stupu kod Sarajeva, GZM 42, 1930, 211-235.

Daicoviciu, Floca 1937 - C-tin. Daicoviciu, O. Floca, Mausoleul Aureliilor de la Sarmizegetusa. Raport preliminar, Sargetia 1, 1937, 1-23.

Daicoviciu et alli 1975 - H. Daicoviciu, D. Alicu, E. Nemeş, I. Piso, C. Pop, Adriana Rusu, Principalele rezultate ale săpăturilor din 1973-1974 la Ulpia Traiana Sarmizegetusa şi semnificația lor, Sargetia 1112, 1974-1975, 252-232.

Floca 1936-1940 - O. Floca, Cercetări arheologice în Munții Zlatnei, pe Dealul Boteş şi Corabia. Raport înaintat Comisiunii Monumentelor Istorice, secția pentru Transilvania, Cluj, în AISC 3, 19361940, 30-173.

Floca, Valea 1965 - O. Floca, M. Valea, Vila rustica şi necropola de la Cinciş, în AMN 2 1965, 163194.

Garašanin 1968 - M. Garašanin, Razmatraja o necropolama tipa Mala Kopašnica-Sase, God. CBI, 4, 1968, 5-35.

Jovanović 1984 - Al. Jovanović Rimske Necropole na teritoria Jugoslavije. Beograd, 1984.

Kosorić, Totorović 1995 - M. Kosorić, J. Totorović, „Grad” Nasele Jutobrdske Kulturne Grune, Starinar, 13-14, 1962-1963 (1965), 267-274.

Mikulčić 1975 - I. Mikulčić, Raznocarski skeletni grobovi iz Skupa, Starinar 24-25, 1973-1974 (1975), $89-102$.

Moga et alii 2003 - V. Moga, C. Inel, A. Gligor, A. Dragotă, Necropola de incinerație din punctul Hop. Alburnus Maior I, 2003, 193-251.

Ortalli 1998 - J. Ortalli, Riti, usi e corredi funerari nelle sepolture romane della prima età imperiale in Emilia Romagna (valle del Po), Bestattungssitte und Kulturelle Identität. Grabanlagen und Grabbeigaben der frühen Römischen Kaiserzeit in Italien und den Nordwest-Provinzen. Kolloquium in Xanten vom 16 bis 18 Februar 1995. Römische Gräber des 1 Jhs. n. Chr. in Italien und Nordwestprovinzen, Xanten, 1998, 49-86.

Petrovsky 1979 - R. Petrovsky, Tipuri de morminte romane în zona Caransebeşului, în Banatica 5, 1979, 201-213.

Protase 1974 — D. Protase, Necropola oraşului Apulum. Săpăturile din anii 1970-1971, în Apulum 12, 1974, 134-159.

Rusu 1979 - Adriana Rusu, Cercetări în necropola Muncelului Brad, în MCA 13, 1979, 219-223.

Rusu-Bolindeț et alii 2003 - Viorica-Rusu Bolindeț, C. Roman, Em. Bota, Adriana Isac, Adela Paki, F. Marcu, Monica Bodea, Forme de habitat în punctul Balea, în Alburnus Maior I, 387-431.

Schucany 2000 - C. Schucany, An elite funerary enclosure in the centre of the villa of BiberistSpitalhof (Switzerland) - a case of study, Burial, Society and Context in the Roman World, Oxford, 2000, 118-126.

Simion et alii 2004 - Mihaela Simion, V. Apostol, D. Vleja, Monumenul funerar circular, în Alburnus Maior II. 2004.

Strejović 1963 - D. Strejović, Rimske Nekropole panog Harstra i Jugoslaviji, Starinar, 13-14, 19621963, 49-88. 
Topál 1993 - Judit Topál, Roman cemeteries of Aquincum, Pannonia, The Western Cemetery in Bécsi Road I, Budapesta, 1993.

Topal 2000 - Judit Topál, The connection between funerary rites and ethnic groups in the cemeteries of north-eastern Pannonia, Burial, Society and Context in the Roman World, Oxford, 2000, 197-203.

Velcea, Savu 1982 - Valeria Velcea, Al. Savu, Geografia Carpaților si a Subcarpaților româneşti, Bucureşti, 1982.

Zotović 1968 - Lj. Zotović, Nekropole spaljenih pokojnika na teritoriji Gornje Mesije, Leskovački Zbornik, 8, 1968, 19-30.

Zotović, Jordović 1990 — Lj. Zotović, Č. Jordović, Nekropola Više Grobalja, Viminacium I, Beograd 1990.

\section{ILLUSTRATION LIST}

Pl. 1. Roşia Montană, Tăul Secuilor cremation necropolis; general plan of the funerary enclosure.

Pl. 2. Roşia Montană, Tăul Secuilor cremation necropolis; inner stratigraphy of the funerary enclosure.

Pl. 3. Roşia Montană, Tăul Secuilor cremation necropolis; Grave 268, plan and profile.

Pl. 4-6. Roşia Montană, Tăul Secuilor cremation necropolis; funerary inventory.

Pl. 7. Roșia Montană, Tăul Secuilor cremation necropolis; Grave 270, plan and profile.

Pl 8. Roşia Montană, Tăul Secuilor cremation necropolis; funerary inventory.

Pl. 9. Roşia Montană, Tăul Secuilor cremation necropolis; Grave 271, plan and profile.

Pl. 10-11. Roşia Montană, Tăul Secuilor cremation necropolis; funerary inventory.

Pl. 12. Roşia Montană, Tăul Secuilor cremation necropolis; objects found outside the graves.

\section{PRELUCRARE ILUSTRAṬIE}

Cătălina Mihaela Neagu

\section{AUTORI}

\section{Cătălina Mihaela Neagu}

Muzeul Naţional de Istorie a României

catalina_mihaela_n@yahoo.com

\section{Ionut Bocan}

Muzeul Naţional de Istorie a României

ionutzbocan@gmail.com 